九州大学学術情報リポジトリ

Kyushu University Institutional Repository

Effects of Dietary Tricalcium Phosphate on the Growth, Feed Efficiency and Mineralization of Bone in Young Red Sea Brearn

Hossain, M. Amzad

Fishery Research Laboratory, Faculty of Agriculture, Kyushu University

Furuichi, Masayuki

Fishery Research Laboratory, Faculty of Agriculture, Kyushu University

https://doi.org/10.5109/24327

出版情報: 九州大学大学院農学研究院紀要. 44 (3/4)，pp.265-271，2000-02. Kyushu University バージョン：

権利関係 : 


\title{
Effects of Dietary Tricalcium Phosphate on the Growth, Feed Efficiency and Mineralization of Bone in Young Red Sea Bream*
}

\author{
M. Amzad Hossain and Masayuki Furuichi \\ Fishery Research Laboratory, Faculty of Agriculture, Kyushu University \\ Tsuyazaki, Fukuoka 811-3304, Japan \\ (Received October 20, 1999 and accepted November 5, 1999)
}

\begin{abstract}
A rearing experiment was conducted for a 12 weeks period to investigate the effects of dietary tricalcium phosphate (TCP) on young red sea bream in aspects of growth, feed utilization and bone mineralization. The fish fed the diet with a low level $(0.2 \%)$ of $\mathrm{Ca}$ supplement from TCP (diet 2) showed growth similar to the fish fed $0.2 \% \mathrm{Ca}$ from Ca-lactate (diet 1). Fish fed the diet with a high level (2.5\%) of Ca supplement from TCP (diet 3) showed sigrificantly poor growth than the fish fed diet 1 . Feed efficiency and condition factor were lower in the fish fed diets 2 and 3 compared to diet 1 . TCP in the diets 2 and 3 decreased the $\mathrm{Zn}$ content of bone. These results indicate tlat. inclusion of a high level of TCP to the purified diet decreases the growth, feed efficiency and $\mathrm{Zn}$ content of bone in red sea bream.
\end{abstract}

\section{INTRODLCTION}

It has been reported that dietary tricalcium phosphate negatively affects the growth and normal mineral contents, particularly $\mathrm{Zn}$ and $\mathrm{Mn}$ contents, in some fresh water fish (Watanabe et al., 1988, 1997). Satoh et al. (1987a) observed that supplementation of $7 \%$ TCP to a semi-purified diet greatly reduced growth rate and feed efficiency and whole body $\mathrm{Zn}$ concentration in rainbow trout. The availability of $\mathrm{Zn}$ from fish meal diets was low to some salmonids due to the presence of TCP derived from hard tissues (Hardy and Shearer, 1985; Satoh et al., 1987b). In contrast to the fresh water species, studies on the effects of TCP on marine fish are scarcely available. We observed recently that TCP in a diet affects the growth and mineral contents of bone in tiger puffer (Hossain and Furuichi, 1998). On the other hand, although dietary TCP affected the mineral contents of bone, there was no effect of TCP on the growth in redlip mullet (Hossain and Furuichi, 2000 ). In the present, study the effects of dietary TCP on red sea bream have been investigated.

\section{MATERIALS AND METHODS}

\section{Experimental Diets}

Three casein based purified diets were formulated as diet $1(0.2 \%$ supplemental $\mathrm{Ca}$ from Ca-lactate), diet 2 (0.2\% supplemental $\mathrm{Ca}$ from tricalcium phosphate, TCP) and diet 3 (2.5\% supplemental Ca from TCP). The compositions of the diets are shown in Table 1.

\footnotetext{
* Contribution from the Fishery Research Laboratory, Kyushu University (No. 248).
} 
The process of diet preparation was similar to that reported in the previous paper (Hossain and Furuichi, 1999b). The proximate and mineral compositions of the dicts are presented in Table 2.

Table 1. Composition of the experimental diets for rod sca broam

\begin{tabular}{lccc}
\hline Diet no. & 1 & 2 & 3 \\
\hline Casein & 50 & 50 & 50 \\
Amino acid mix*1 & 4 & 4 & 4 \\
$\alpha$-Potato starch & 7 & 7 & 7 \\
Dextrin & 10 & 10 & 10 \\
Pollack liver oil & 10 & 10 & 10 \\
Vitamin mix*? & 3 & 3 & 3 \\
Mineral mix*:3 & 5 & 5 & 5 \\
Ca-lactatc & 1.54 & - & - \\
Cas(POi) & - & 0.52 & 6.52 \\
Carboxymethylcellulose & 4 & 4 & 4 \\
$\alpha$ Cellulose & 5.46 & 6.48 & 0.48 \\
\hline
\end{tabular}

*: Amino acid mixture: arginine $\cdot \mathrm{HCl}$, alarine, glycine, and aspartate $\cdot \mathrm{Na}, 25 \%$ each.

${ }^{* 2}$ Halver (1957).

*3 Mirteral mix (in $100 \mathrm{~g}$ mixture): Major element in g: $\mathrm{KCl} 7.68, \mathrm{MgSO}_{4} \cdot 5 \mathrm{H}_{2} \mathrm{O}$ 8.16, $\mathrm{NaH}_{4} \mathrm{PO}_{4} \cdot 2 \mathrm{H}_{2} \mathrm{O}$ 68.52, $\mathrm{Fe}$-citrate 2.40 , and ccllulose 12.69 ; Minor clement in mg: $\mathrm{AlCl}_{4} \cdot 6 \mathrm{H}_{4} \mathrm{O} 90.0, \mathrm{ZnSO}_{4} \cdot 7 \mathrm{H}_{2} \mathrm{O} 264.0, \mathrm{MnSO}_{4} \cdot 5 \mathrm{H}_{2} \mathrm{O} \quad 175.3$, $\mathrm{CuCl} 15.7, \mathrm{Kl} 3.7$, and $\mathrm{CoCl}_{2} \cdot 6 \mathrm{H}_{2} \mathrm{O} 1.3$.

Table 2. Proximate and mineral compositions of the experimental diets for red sca bream

\begin{tabular}{|c|c|c|c|}
\hline Diet no. & 1 & 3 & 4 \\
\hline \multicolumn{4}{|l|}{ Proximate composition } \\
\hline Moisture (\%) & 20.9 & 20.9 & 20.9 \\
\hline Crude protein $(\% \mathrm{db})$ & 51.3 & 52.6 & 52.8 \\
\hline Crude lipid ( $\%$ db) & 9.1 & 9.4 & 9.0 \\
\hline Crude ash $(\%$ db) & 5.1 & 5.4 & 11.0 \\
\hline \multicolumn{4}{|c|}{ Mineral composition $(\mathrm{db})$} \\
\hline $\mathrm{Ca}(\%)$ & 0.24 & 0.23 & 2.54 \\
\hline $\mathrm{P}(\%)$ & 1.00 & 1.12 & 2.37 \\
\hline$K(\%)$ & 0.19 & 0.19 & 0.19 \\
\hline $\mathrm{Mg}(\mu \mathrm{g} / \mathrm{g})$ & 420 & 370 & 430 \\
\hline $\mathrm{Fe}(u \mathrm{~g} / \mathrm{g})$ & 280 & 290 & 300 \\
\hline $2 n(\mu g / g)$ & 48 & 48 & 42 \\
\hline $\operatorname{Mn}(\mu \mathrm{g} / \mathrm{g})$ & 16 & 15 & 17 \\
\hline $\mathrm{Cu}(\mu \mathrm{g} / \mathrm{g})$ & 11 & 14 & 11 \\
\hline
\end{tabular}

* db, dry basis. 


\section{Experimental Fish and Rearing Methods}

Young red sea bream (Pagrus major) produced and reared in Fishery Research Laboratory, Kyushu Lniversity, were used for the experiment. The fish were acclimatized in the indoor flow-through aquaria for 2 wceks, during which they were fed the experimental dict 1 . On the beginning of the experiment, fish were weighed individually, selected and distributed to $150 \ell$ aquaria in such a manner that average body weight and size variations in three experimental groups were almost similar. The number of fish in a group was 30 (av. body wt. 11.5g).

The fish were reared for a 12 weeks period, during which cxperimental diets were fed to satiation 2 times a day at 0900 and $1530 \mathrm{~h}$. Rearing temperature ranged from 20.0 to $24.0^{\circ} \mathrm{C}$. Sand-filtered sea water was supplied to the aquaria continuously at a flow rate of $3-4 \ell / \mathrm{min}$. Biweekly weighing and other rearing methods were the same as those reported previously (Hossain and Furuichi, 1999).

\section{Sample Collection and Analytical Methods}

At the end of the feeding experiment, the fish were starved for $15-20 \mathrm{~h}$ and anaesthetized with MS-222. Body length and body weight were measured. Then, blood samples were collected from the cuvierian duct with a $1 \mathrm{ml}$ heparinized syringe. Liver was collected immediately from all the fish and weighed to calculate the hepatosomatic index and preserved at $-20^{\circ} \mathrm{C}$ for further analyses. After removing the internal organs, the whole body was washed with distilled water and preserved at $-20^{\circ} \mathrm{C}$ for bone collection.

Determinations of hematological characteristics and proximate and mineral compositions of the diet, liver and bone were the samc as those described previously (Hossain and Furuichi, 1999).

The data, when applicable, were subjected to analysis of variance, and significance of difference $(P<0.05)$ was determined by the Fisher's PLSD test.

\section{RESULTS}

The change in body weight over the experimental period is shown in Fig. 1. The differences in the average body weights were noticed from the 6 th week of the experiment, indicating the need of a relatively longer period for the experiment with $\mathrm{Ca}$ requirement. At the end of the experiment, survival rate was $93.3 \%$ in all the treatments (Table 3). The maximum growth was obtained in the fish fed diet 1 containing easily digestible Ca $(0.2 \%)$ from Ca-lactate. The fish fed diet 2 supplemented with a low level of TCP $(0.2 \% \mathrm{Ca})$ showed the statistically same growth as that of the fish fed diet 1 . Significantly poor growth was observed in the fish fed diet 3 supplemented with a high lcvel of TCP ( $2.5 \% \mathrm{Ca}$ ) compared to the fish fed other two diets. Daily feed consumption was higher in the fish fed diets 2 and 3 with TCP supplements than the fish fed control diet 1. However, a high level of dietary TCP decreased the feed efficiency and condition factor of fish.

The hematocrit value, and hemoglobin and plasma protein contents were similar in fish fed all the diets (Table 4). Plasma tryglyceride was slightly higher in the fish fed diets 2 and 3 compared to the fish fed diet 1 . No difference was noticed in plasma $\mathrm{P}, \mathrm{Ca}$, $\mathrm{Mg}$ and $\mathrm{Fe}$ contents among the fish fed different diets. 


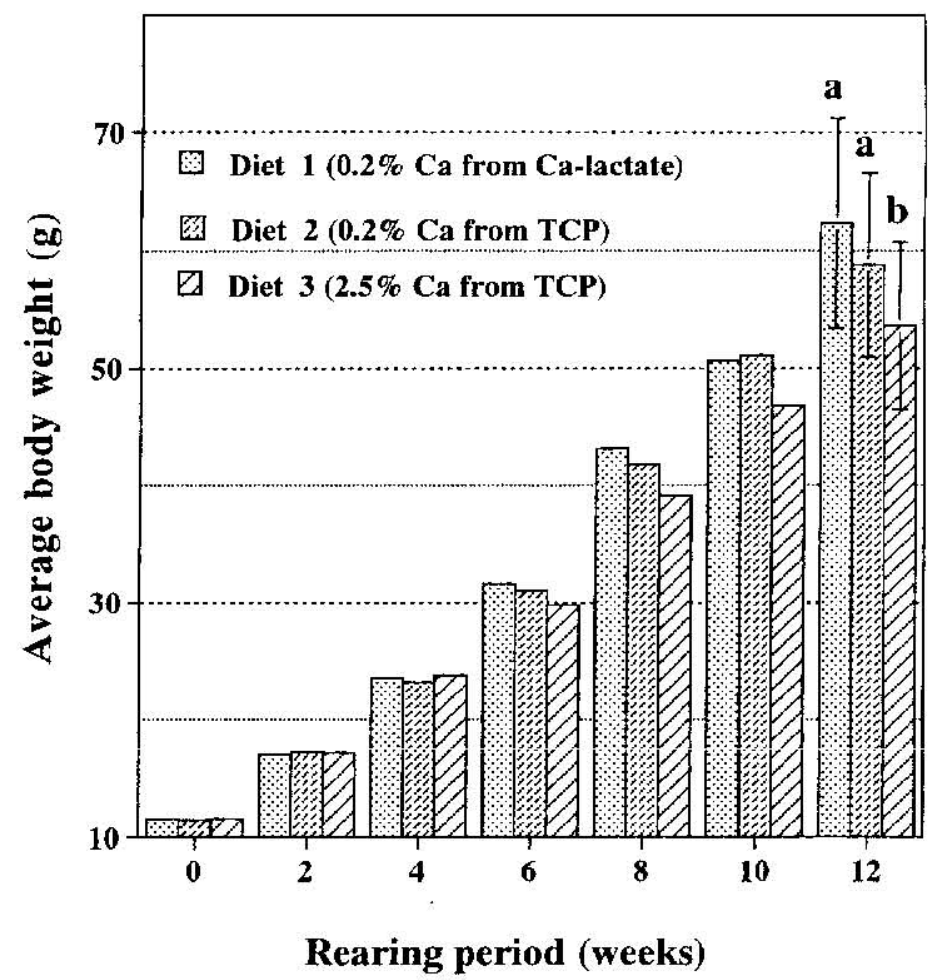

Fig. 1. Growth of red sea bream fed the experimental dicts. At the end of 12 weeks rearing, different letters indicate significant differences $(P<0.05$, Fisher's PLSD test $)$.

Table 3. Growth and feed utilization of red sea bream fed the experimental diets

\begin{tabular}{lccc}
\hline Diet no. & 1 & 2 & 3 \\
\hline Av. body wt. (g) & & & \\
Initial & $11.6 \pm 0.9$ & $11.5 \pm 0.8$ & $11.6 \pm 0.8$ \\
Final* & $62.3 \pm 8.9^{\prime \prime}$ & $58.8 \pm 7.8^{*}$ & $53.6 \pm 7.1^{\prime \prime}$ \\
Weight gain (\%) & 437 & 411 & 362 \\
Daily focd consumption & 2.28 & 2.35 & 2.41 \\
(\% of body wt.) & & & \\
Feed efficiency (\%) & 91.8 & 86.6 & 80.6 \\
Condition factor* & $3.61 \pm 0.18^{*}$ & $3.55 \pm 0.13^{\text {a* }}$ & $3.46 \pm 0.22^{\prime \prime}$ \\
Survival rate (\%) & 93.3 & 93.3 & 93.3
\end{tabular}

* Values (mean $\pm \mathrm{SD}$ ) in the same row bearing different letters are significantly different $(P<0.05$, Fisher's PLSD test). 
Table 4. Blood characteristics of red sea bream fed the experimental diets

\begin{tabular}{lccc}
\hline Diet no. & 1 & 2 & 3 \\
\hline Hematocrit $(\%)^{*}$ & $28.9 \pm 3.5$ & $28.8 \pm 3.9$ & $30.5 \pm 2.7$ \\
Hemoglobir $(\mathrm{g} / 100 \mathrm{ml})^{*}$ & $4.7 \pm 1.1$ & $4.8 \pm 0.9$ & $4.7 \pm 0.6$ \\
Plasma protein $(\mathrm{g} / 100 \mathrm{ml}) *$ & $4.3 \pm 0.6$ & $4.1 \pm 0.6$ & $4.1 \pm 0.4$ \\
Plasma triglyceride $(\mathrm{mg} / 100 \mathrm{ml})$ & 448 & 490 & 498 \\
Plasma P (mg/100 & 11.7 & 9.6 & 10.6 \\
Plasma Ca $(\mathrm{mg} / 100 \mathrm{ml})$ & 13.8 & 12.3 & 13.1 \\
Plasma $\mathrm{Mg}(\mathrm{mg} / 100 \mathrm{ml})$ & 4.5 & 4.9 & 4.6 \\
Plasma Fe $(\mathrm{mg} / 100 \mathrm{ml})$ & 86 & 100 & 97 \\
\hline
\end{tabular}

* No significant difference $(P>0.05$, Fisher's PLSD test).

Table 5. Proximate composition of liver and hepatosomatic index of red sea bream fed the experimerital diets

\begin{tabular}{lccc}
\hline Diet no. & 1 & 2 & 3 \\
\hline Moisture (\%) & 65.0 & 64.8 & 66.9 \\
Crude protein $(\% \mathrm{db})^{* 2}$ & 30.3 & 30.7 & 29.9 \\
Crude lipid $(\% \mathrm{db})$ & 39.4 & 41.2 & 35.0 \\
Crude ash $(\% \mathrm{db})$ & 31.0 & 31.0 & 36.0 \\
Glycogen $(\% \mathrm{db})$ & 10.0 & 23.3 & 26.6 \\
HSI $(\%)^{*}$ & 2.33 & 2.17 & 2.26 \\
\hline
\end{tabular}

*1 db, dry basis.

*2 Hepatosomatic index: liver weight $(\mathrm{g}) \times 100 /$ body weight $(\mathrm{g})$.

Table 6. Lipid, ash and mineral contents in the vertebrae of red sea brcam fed the experimental diets (dry basis)

\begin{tabular}{lccc}
\hline Diet no. & 1 & 2 & 3 \\
\hline Crude lipid (\%) & 20.6 & 21.1 & 22.4 \\
Crude ash (\%) & 54.3 & 53.3 & 53.4 \\
Ca (\%) & 27.5 & 26.2 & 26.9 \\
P (\%) & 11.4 & 10.2 & 10.0 \\
Mg (\%) & 0.23 & 0.22 & 0.21 \\
K ( $\mu \mathrm{g} / \mathrm{g})$ & 122 & 130 & 131 \\
$\mathrm{Fe}(\mu \mathrm{g} / \mathrm{g})$ & 50.2 & 51.1 & 47.7 \\
$\mathrm{Zn}(\mu \mathrm{g} / \mathrm{g})$ & 66.7 & 55.1 & 56.1 \\
$\mathrm{Mn}(\mu \mathrm{g} / \mathrm{g})$ & 25.4 & 28.3 & 24.1 \\
$\mathrm{Cu}(\mu \mathrm{g} / \mathrm{g})$ & 1.8 & 2.7 & 3.0 \\
\hline
\end{tabular}


Moisture and protein contents of the liver were almost similar in all the fish, but low lipid and slightly higher ash contents were detected in the fish fed diet 3 (Table 5). Liver glycogen contents were higher in the fish fed diets 2 and 3 than the fish fed diet 1. Hepatosomatic index values were similar in fish fed all the diets.

The results of bone analyses are presented in Table 6 . Bone lipid and ash contents were similar in all the fish. $\mathrm{Ca}, \mathrm{P}, \mathrm{Mg}, \mathrm{Mn}$ and $\mathrm{K}$ contents of bone were not affected by dietary TCP. However, dietary TCP decreased Fe and $\mathrm{Zn}$ contents and increased $\mathrm{Cu}$ content of bone.

\section{DISCLSSION}

A high level of Ca from TCP decreased the growth of red sea bream. On the other hand, a low level of Ca from TCP did not affect the growth. These indicale that only a high level of TCP in the diet affects the growth of red sea bream. In the previous studies, decreased weight gain and low bone mineral contents were observed in tiger puffer fed the diets supplemented with TCP (Hossain and Furuichi, 1998). On the other hand, dietary TCP affected bone mineral contents but not the weight gain in redlip mullet (Hossain and Furuichi, 2000). Satoh et al. (1987a) reported that a high level of TCP $(7 \%)$ in a semi-purified diet reduced the growth and feed efficiency of rainbow trout and supplementation of $80 \mu \mathrm{g} \mathrm{Zn/kg}$ diet was necessary to obtain the normal growth, feed efficiency, and mineral contents of whole body similar to those in fish fed a TCP-free diet with $40 \mu \mathrm{g} \mathrm{Zn/kg}$. They suggested that dielary TCP affected the availability of $\mathrm{Zn}$ from a diet to fish. In the present study, low levels of Zn contents was found in the bone of fish fed TCP supplemented diets. The inhibitory effect of dietary TCP to the bioavailability of Zn have been reported in some other studies (Hardy and Shearer, 1985; Satoh et al., 1987b; Gatlin and Phillips, 1989). However, no effect of supplemental dietary TCP on weight gain and $\mathrm{Zn}$ content in vertebrae was found in case of channel catfish (Satohet al., 1989). Satoh et al. (1991) observed that the availability of Mn from white fish meal was low in rainbow trout and suggested that, similar to in case of $\mathrm{Zn}$. TCP in white fish meal may reduce the availability of $\mathrm{Mn}$. However, bone $\mathrm{Mn}$ content, in the present study, did not alfect by dietary TCP.

From the above resulis, it may be conciuded that an excessive TCP supplement to a diet affects the growth, feed utilization and $\mathrm{Zn}$ content in bone of red sea brearm.

\section{ACKNOWLEDGEMENTS}

We wish to express our sincere thanks to Dr. Seiichi Matsui and Dr. Takao Yoshimatsu of our laboratory for their suggestions and assistance in this study.

\section{REFERENCES}

Gatlin, D. M., III and H. F. Phillips 1989 Dietary calcium, phytate and zinc interactions in charuel catfish. Aquaculture, 79: 259-266

Halver, J. E. 1957 Nutrition of salmonid fishes. III. Water-soluble vitamin requirements of chinook salmon. J. Nutr., 62: 225-243

Hardy, R. W. and K. D. Shearer 1985 Effect of dietary calcium phosphate and zinc supplementation on whole body zinc concentration of rainbow trout (Salmo gairdneri). Can. J. Fish. Aqual. Sci., 42 : 
181-184

llossain, M. A. and M. Furuichi 1998 Availability of environmental and dietary caleium in tiger puffer. Aquacult. Int., 6: 121-132

Hossain, M. A. and M. Furuichi 1999 Effect of deletion of cialeium supplement from purified diet on growth and bone mineralization in red sea bream. f. Fac. Agr., Kzushu Lnit., 44: 91-97

Hossain, M. A. and M. Furuichi 2000 lissentiality of dietary calcium supplement in redlip mullet Liza hatmalocheila. Aquacult. Nutr., 6: (in press).

Satoh, S., W. E. Poe and R. P. Wilson 1989 The effect of supplemental phytate and/or tricalcium phosphate on weight gain, feed efficiency and $\mathrm{Zn}$ content in vertebrae of channel catfish. Aquaculture, 80: $155-161$

Satoh, S., K. Tabata, K. Izume, T. Takeuchi and T. Watanabe 1987a Effect of dietary tricalcium phosphate on availability of zine to rainbow trout. Nippon Suisam Gakkoishi, 53:1199-1205

Satoh, S., T. Takeuchi and T. Watanabe $1987 \mathrm{~b}$ Availability to rainbow trout of zinc in white fish meal and of various zine compounds. Nipport Suisun Gukkuisti, 53: $595-599$

Satoh, S., 'T. T'akcuchi, and T. Watanabe 1991 Availability of manganese and magnesium containcd in white fish meal to rainbow trout Onchorynchus mykiss. Nipopon Suisan Gakkaishi, 57: 99-104

Watamabe, T., V. Kiron and S. Satoh 1997 Trace minerals in fish nutrition. Aquaculture, 151: 185-207

Watanabe, T., S. Satoh and T. Takeuchi 1988 Availability of minerals in fish meal to fish. Asian Fish. Sci., 1: $175-195$ 